\title{
Legal Protection of Vaccine Administration Health Service to Prevent the Spread of the Coronavirus Disease 2019 in Indonesia
}

\author{
Arief Budiono ${ }^{1 *}$, Dewi Iriani ${ }^{2}$, Martha Eri Safira ${ }^{2}$, Rif'ah Roihanah ${ }^{2}$, Muhamad Noor ${ }^{3}$, Neneng Uswatun Khasanah ${ }^{4}$, Ridwan Ridwan $^{5}$ \\ ${ }^{1}$ Department of Law, Universitas Muhammadiyah Surakarta, Surakarta, Indonesia; ${ }^{2}$ Faculty of Shariah, Institut Agama Islam \\ Negeri Ponorogo, Ponorogo, Indonesia; ${ }^{3}$ UIN Sultan Aji Muhammad Idris, Samarinda, Indonesia; ${ }^{4}$ Universitas Darussalam \\ Gontor, Ponorogo, Indonesia; ${ }^{5}$ Sekolah Tinggi IImu Hukum Muhammadiyah Bima, Indonesia,
}

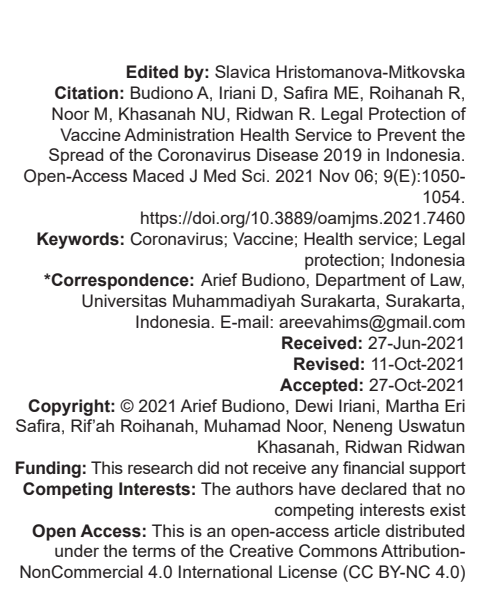

Abstract

BACKGROUND: The increase of Coronavirus disease (COVID-19) infections leads countries to implement preventive steps such as wearing masks, social distancing, and vaccine administration. Indonesia started administering mass vaccination in January 2021 using the Sinovac vaccine, but there are still problems such as the emergence of side effects.

AIM: This research aims to explain the legal protection of COVID-19 vaccine administration and its obstacles.

METHODS: This is a normative legal study that uses library research. It uses the statute approach.

RESULTS: The research results show that the legal protection of COVID-19 vaccine administration includes Law No. 36 of 2009 on Health and Presidential Decree No. 99 of 2020 on Vaccine Procurement and Administration to Overcome the COVID-19 Pandemic. Then, the obstacles in the vaccine administration include the limited stock of vaccines and supporting health equipment such as hazmat suits and injection needles.

CONCLUSION: Thus, the government of Indonesia should implement the Health Protocols during this pandemic, as stipulated in the Decree of the Republic of Indonesia's Ministry of Health No. Hk.01.07/Menkes/382/2020.

\section{Introduction}

At the end of 2019, a new virus emerged, named the coronavirus disease 2019 (COVID-19) [1]. On April 14, 2021, 108.384 people in Indonesia were actively infected by the COVID-19, 74.158 specimens, 58.580 suspects, 1.583.182 confirmed, 1.431 .892 recovered, and 42.906 deaths. Central Java was the province with the highest recovery rate, with 1.780 recovered cases [2].

All countries have made efforts in seeking recovery through medical treatments. Mass vaccination started in January 2021. There are still obstacles that led to the increase of COVID-19 pandemic cases. On October 5, 2020, the President of Indonesia issued Presidential Decree No. 99 of 2020 on Vaccine Procurement and Administration to Overcome the COVID-19 Pandemic (PD99 on Vaccines). The mass vaccine administration has led to side effects, including fever, headache, pain in the arm, and even two reported cases of post-vaccination death. The government must provide maximum security on health services by giving legal protection as stated in Law No. 36 of 2009 on Health. Article 1 number 11 of this law stipulates, "To provide sustainable health for the society through the increase of health in the form of treatments toward diseases, giving efforts to heal the people." Article 5 states that every person has the right to health. Then, article 14 regulates the government's responsibility to coach, regulate, supervise, and plan evenly distributed and affordable health for the people.

From the background above, the research questions are: (1) How is the legal protection of health services regarding the COVID-19 vaccine administration in Indonesia? (2) What are the obstacles of COVID-19 vaccine administration and the prevention of this disease in Indonesia? These two questions will be discussed in this paper.

\section{Research Method}

This is a normative legal study that uses library research. It uses the statute approach on PD99 on vaccines. This research was conducted in East Java province and Central Java Province from April 2020 to February 2021. 
This study uses the case study method of analysis and the descriptive-qualitative method. It uses the theories of legal protection and health law to analyze the problems.

\section{Results}

\section{Legal protection on vaccines}

Some countries have started administering the COVID vaccine, including Indonesia. The Indonesian government ordered the Sinovac vaccine and it has been clinically tested from October 2020 to January 2021 [3]. Problems occurred because the Sinovac is less effective than Astrazeneca or Moderna. This case led to the high arises of COVID-19 patient after vaccinated (Figure 1).

The first person in Indonesia to be vaccinated by the Chinese-made vaccine (Sinovac) was the Republic of Indonesia's President, Joko Widodo (Figure 2). It was followed by state officials, religious leaders, health workers, academia, and other people. The vaccination is carried out in two doses, with around 1 and 2 weeks in between.

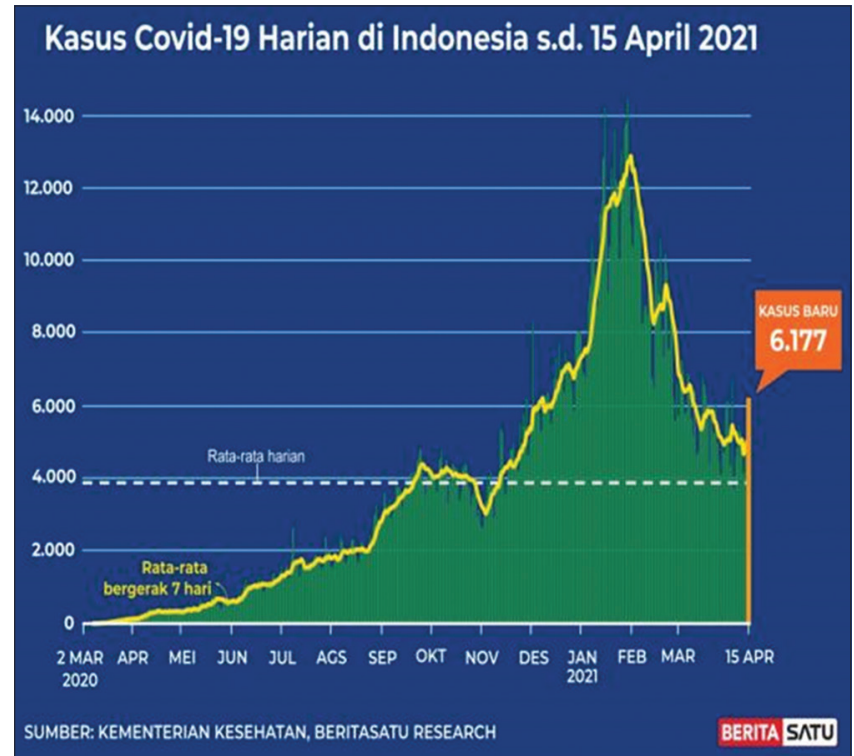

Figure 1: The daily coronavirus disease-19 cases in Indonesia (Updated April 15, 2021) [17]

There were deaths of health workers and people due to the COVID-19 pandemic. The government hopes that there will be no more deaths after the COVID-19 vaccination. Hindra Irawan Satari, Head of the National Commission of Post-Immunization Follow-Up Events (Kejadian Ikutan Pasca Imunisasi) stated that after being vaccinated, people may still be infected by the COVID-19. This is because the antibody will be formed around 28 days after the vaccination [4].

A nurse from Blitar, East Java, named Erny Kusuma Sukma Devi died 9 days post-vaccination. It is found that she was infected by COVID-19. Lab results show that she did not have any congenital diseases, but she had obesity [5]. Then, a police inspector from Maluku named Doni died after participating in mass vaccination on March 30, 2021. Five days postvaccination, examination results show that he was infected by COVID-19 [6].

The vaccine recommended by the government for the Indonesian citizens is certainly not chosen at random, as there had been holistic considerations and clinical examinations. The government has the responsibility to give legal protection to the society, to guarantee legal certainty and justice based on Law No. 36 of 2009 on Health [7].

Law No. 36 of 2009 on Health, articles 14 to 19 regulate the government's responsibility toward the public health services by educating the society on health, providing a healthy environment, and providing health facilities and infrastructure. This is parallel to Article 15 and Article 21 clause (7) of PD99 on vaccines, where the government with the Ministry of Health and the National Agency of Drug and Food Control in all provincial regions will carry out post-COVID-19 mass vaccination monitoring, implemented by the National Committee, the Regional Committee, and the PostImmunization Follow-Up Event Assessment and Countermeasure Work Unit.

The writer believes that health service legal protection cannot be separated from the government's responsibility. The government issued Law No. 36 of 2009 and PD99 on vaccines as legal protection. The writer will further explain theories on legal responsibility and legal protection. Moral and ethical responsibility creates legal rights to demand to other people, meanwhile, the obligation to become responsible for one's actions gives legal protection [8].

Muhammad [9] explains a theory on the responsibility of law-violating actions or tort liability; intentional tort liability, negligence tort liability, the concept of fault, ethical law violation, and responsibility toward both intentional and non-intentional actions.

Research results from Sukendar and Aris found that the creation of legal protection facilities includes:

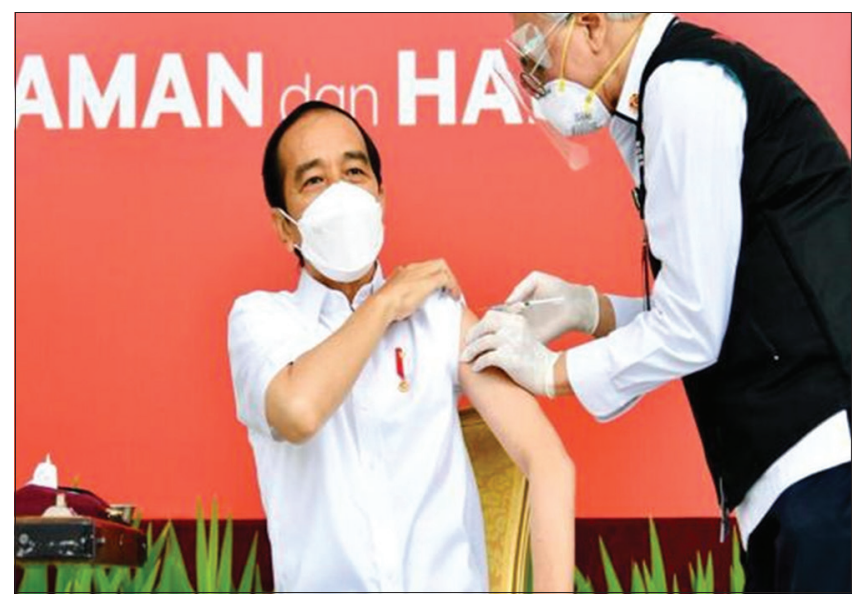

Figure 2: President Joko Widodo receives coronavirus vaccine [18] 
(1) Preventive legal protection, which is the prevention from errors or crime and (2) repressive legal action is when an error or an event with legal consequences had occurred [10].

Then, Santoso et al. stated that the government gives legal protection to its citizens by guaranteeing citizen rights, preventing impacts that may occur, and giving compensation [11].

Some of the people who have undergone mass vaccination experienced side effects of that vaccine, from light symptoms to severe ones. Even though there are only a few fatalities, the government must be more careful in administering the vaccines to society by tracking their contact with COVID-19 patients and taking note on their congenital diseases. If necessary, the government should provide free health check-ups before obtaining the vaccine, including rapid test, swab/polymerase chain reaction (PCR), antigen, or GeNose. In the cases where people died after being vaccinated, the death is not due to the vaccine as it was due to COVID-19 or congenital diseases. However, the government must still be responsible to give legal protection by providing compensation to the families of those who died.

\section{Obstacles in vaccine administration}

The present on-going vaccination does not run easily nor is obstacle-free as was planned. There are certainly some challenges and obstacles. The Minister of Health, Budi Gunadi Sadikin through Kompas.com, stated that the obstacle in vaccine administration is not the location of vaccine injection, but the problem lies in the vaccine stock. The government has prepared 10 million vaccine doses from January to February 2021. However, Indonesia was only able to inject 100 thousand people per day, though it was necessary to inject a million people a day in the whole nation. Then, at the end of May-June, there is the target of 25 million vaccine doses, thus the injection capacity is increased to 500 thousand to 1 million per day. Then, in the first semester, the state will reach the target of $75 \%$ vaccines. Then, it will be continued in the second semester (June to December). The target of vaccine injection in the whole of Indonesia is 5.4 million and 4 million people. It is then continued with the target of 38 million people in the second semester. The obstacles are not only limited to the vaccine procurement, but also the procurement of injection needles, hazmat suit for health workers, unclear information for elderly people, and the data accuracy of vaccine recipients (Figure 3) [12].

The vaccine administration is only a preventive countermeasure. There is still the chance for vaccinated people to be re-infected by the COVID-19 disease, even though they may only experience light symptoms or even without symptoms at all. There still needs to be preventive measures against the COVID19 pandemic by obeying tight health protocols, which will protect oneself, one's family, and the surrounding

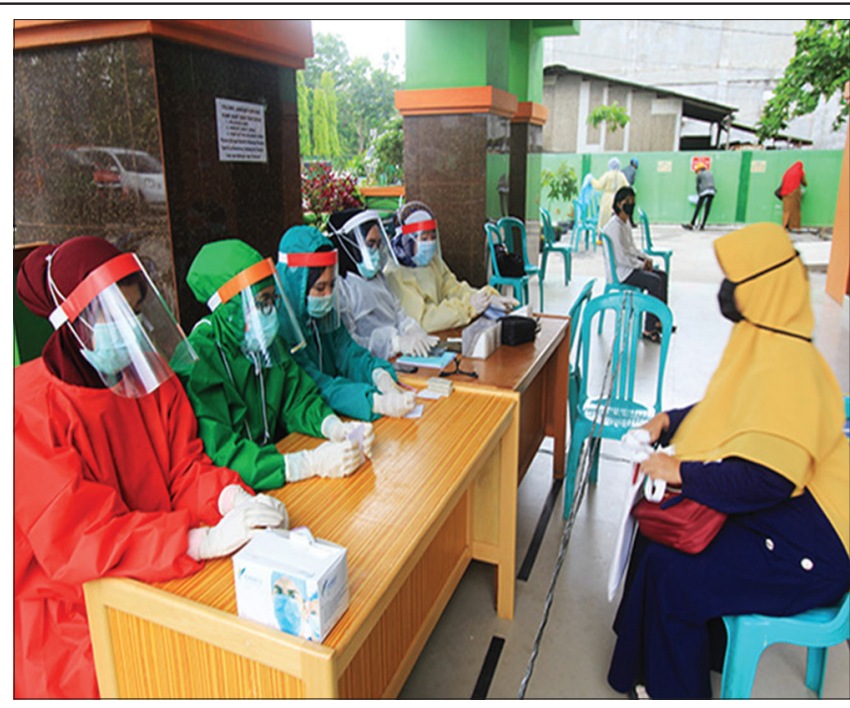

Figure 3: A woman getting ready to be vaccinated [19]

people. These are the efforts to prevent being infected by COVID-19:

\section{Wash hands}

Germs and viruses on the hands will die if they are washed with soap and running water after carrying out some activities. The right method is to wash hands for $20 \mathrm{~s}$, including washing between fingers, the palms, and the back of the hands. If there is no running water available, hand sanitizers are easy to be used and they may be brought anywhere.

\section{Wear mouth/nose covers or masks}

The correct type of mask is that made of cotton not that made of thin polymer. It is better to use the N95 medical mask, which is usually used during medical operations in the surgery room. The correct way of wearing a mask is by covering all parts of the nose, mouth, and up to the lower chin.

\section{Maintaining the body endurance}

Increase the immune by consuming healthy foods, vegetables, fruit, and making homemade drinks from spices, and consuming supplements.

\section{self-isolation}

Social distancing, avoiding crowds, and

Maintaining the physical distance of $2 \mathrm{~m}$, avoiding crowds to minimize the chance to be infected by droplets. If one feels unhealthy, it is better to stay at home. If one experiences coughing, fever, or shortness of breath; it is advised to undergo a COVID19 medical check-up through PCR/swab, antigen, and GeNose tests. If one or one's family is infected by the COVID with heavy symptoms, it is better to be treated 
in the hospital. However, if they only experience light symptoms or without COVID-19 infection symptoms; it is better to carry out self-isolation.

\section{Maintaining the cleanliness of the home}

It is advised to not only take care of the health but to also frequently disinfect furniture at home.

In the aspect of the law, the national vaccine administration is part of the health law scope. The contents of the health law materials include the quality and quantity of health, health rights, health protection, and health facilities [13]. To achieve health goals, health rights indicators must be fulfilled, which include: The availability of health facilities and the procurement of health treatments, the accessibility to information on health, the acceptability of health facilities both for health workers and patients the quality of health service, the scientific knowledge of medical health of health workers, and adequate sanitation [14]. The health law refers to the public health law on health services and medical law, which is the relationship between doctors and patients on health [15].

\section{Discussion}

Research results from the review of online news articles from Kompas.com show that the obstacles of vaccine administration are not only limited to the minimum number of health workers, but it is also due to the procurement of the vaccine itself. The PD99 on vaccines article 1 clause (1) and (2) states that the acceleration of COVID-19 countermeasures is carried out through mass vaccination, which includes the supply of vaccines, the vaccine administration, and the vaccine procurement with the support of institutions and Regional Governments. Article 2 clause (1) to (4) states that the Ministry of Health with the COVID19 Countermeasure and National Economic Recovery Committee work together with PT Bio Farma (Persero) to provide the COVID-19 vaccines by considering ethics, principles, and objectives [16].

Due to the limited supply of Sinovac vaccines from China, some universities in Indonesia carried out research and studies to make Indonesian-made vaccines. This idea is from the ex-Minister of Health, Terawan, who carried out researches with some universities in Indonesia. However, there are still debates as the Minister of Health has approved the Archipelago Vaccine, but the National Agency of Drug and Food Control has not issued the permit. Apart from the Archipelago Vaccine, there is also the Red White Vaccine which is still clinically examined in labs. Article 42 clauses (1) to (3) provides information related to health and the development of health science, including new emerging or re-emerging diseases, public health emergency of international concern/PHEIC which emphasizes benefit sharing and tracking system for Indonesians.

The medical science development on vaccines must be balanced with health protocols in line with the Decree of the Republic of Indonesia's Ministry of Health No. Hk.01.07/Menkes/382/2020 on Health Protocols for the Society in Public Places and Facilities to Prevent and to Handle the COVID-19, by wearing masks outside the house, social distancing, avoiding crowds during outdoor activities, bringing hand sanitizers, providing hand-washing stations at shops and public facilities, and consuming healthy foods. The implication of health protocols is aimed to decrease the rate of COVID-19 infections.

\section{Conclusion}

Legal protections for the people on vaccine administration health service are stipulated in Law No. 36 of 2009 on Health and the Presidential Decree No. 99 of 2020 on Vaccine Procurement and Administration to Overcome the COVID-19 Pandemic. The government carried out clinical examinations of the COVID-19 vaccine to some people who became volunteers from October to December 2020. After being clinically tested as an effective countermeasure against the COVID-19, in January 2021, the government started the Sinovac vaccine administration to the people.

An obstacle in the vaccine administration and the prevention of the COVID-19 is the minimum supply of the Sinovac vaccine, thus it is difficult to distribute this vaccine evenly to all of Indonesia. This limited supply gave the ex-Minister of Health, Terawan, an idea to make Indonesian-made vaccines - the Archipelago Vaccine and the Red White Vaccine - which are currently being studied by some universities according to articles 1 and 2 of the PD99 on vaccines.

The vaccine administration must be balanced with health protocols as stipulated in the Decree of the Republic of Indonesia's Ministry of Health No. Hk.01.07/Menkes/382/2020 on Health Protocols for the Society in Public Places and Facilities to Prevent and to Handle the COVID-19, by wearing masks outside the house, social distancing, and consuming healthy foods. The government also limits the people's mobility, such as prohibiting travels during the Islamic holidays (Eid al-Fitr), but in emergency conditions, people may go to other cities by showing a doctor's letter stating that he/ she is free from COVID-19.

The government should give legal protection to citizens who died after receiving the COVID-19 vaccine, even though their deaths were due to COVID-19 
infection or congenital diseases by giving compensation to the families. This legal protection is a constitutional right of the victims of the COVID-19 vaccine and their families. In the case of a future pandemic, the government must be strict from the start, by closing international flights and by preventing infected people from entering Indonesia.

\section{References}

1. Yuliana. Corona virus diseases (Covid-19): A literature review. J Wellness Healthy Mag. 2020;2(1):56.

2. Rizal JG, Wedhaswary ID. Seeing Deaths Due to Covid-19 in Indonesia. Kompas; 2021. Available from: https://www.kompas. com/tren/read/2020/07/14/073000765/melihat-kematian-akibatcovid-19-di-indonesia-kelompok-usia-berapa-yang?page=all [Last accessed on 2021 Oct 09].

3. Alam SO. Results of the Sinovac Covid Vaccine Test in Bandung will be announced on January $15^{\text {th }}$ by the Food and Drug Agency. Detik Health. Available from: https://health.detik. com/berita-detikhealth/d-5320095/hasil-uji-vaksin-coronasinovac-di-bandung-akan-diumumkan-15-januari-oleh-bpom [Last accessed on 2021 Mar 18].

4. Junitah N. 2 Health Workers Died after being Administered with the Covid-19 Vaccine, this is the Explanation of the Ministry of Health. Newswire; 2021. Available from: https://kabar24. bisnis.com/read/20210223/15/1359752/2-tenaga-kesehatanmeninggal-setelah-disuntik-vaksin-covid-19-begini-penjelasankemenkes [Last accessed on 2021 Apr 27].

5. Hasani AA, Agriesta D. 9 Days After Being Vaccinated, Nurse Emy was Positive of the Covid-19, Died during Hospitalization. Kompas. Available from: https://regional.kompas.com/ $\mathrm{read} / 2021 / 02 / 21 / 15240431 / 9$-hari-setelah-disuntik-vaksinperawat-erny-positif-covid-19-meninggal-saat?page=all

6. Patty RR, Agriesta D. Discussion on the Case of the Death of a Police Brigade Comrade After Being Vaccinated, Positive with Covid-19, and Hospitalized Twice. Kompas. Available from: https://regional.kompas.com/read/2021/04/05/061204278/ duduk-perkara-komandan-brimob meninggal-usai-disuntikvaksin-positif-covid?page=all [Last accessed on 2021 May 30].

7. Koswara IY. Protection of health workers in the regulation of the health sector perspective in relations to the law No. 36 on health and social security system. Hukum Positum. 2018;3(1):1-18.

8. Triwulan T, Febrian S. Legal Protection for Patients. Jakarta: Prestasi Pustaka; 2010. p. 48.
9. Muhammad A. The Indonesian Corporate Law. Bandung: Citra Aditya Bakti; 2020

10. Absori A, Sigit SN, Arief B, Sarjiyati S, Budiono A, Nugroho HS et al. The prospect of environmental law to achieve healthy environmental development in Indonesia. J Med Legal Update. 2020;20(1):204-8.

11. Sukendar, Santoso AP. Criminal Offenses in the Practice of Independent Nursing. Bantul: Nuha Medika; 2019.

12. Santoso AP, Septiarini AD, Rohmah SN, Haryadi AR. Legal protection for health workers in the task force in accelerating the COVID-19 administration from the perspective of state legal administration. In: National Seminar and Call for Papers Hubisnistek; 2020. p. 276.

13. Alika R, Nasution AD. The Target for COVID-19 Vaccination is disturbed by the Number of Health Facilities and Data Issues, Katadata; ???. Available from: https://www.katadata.co.id/ ameidyonasution/berita/6047b8b62d5f7/target-vaksinasi-covid19-terganjal-jumlah-faskes-dan-masalah-data

14. Absori, Arief B. Indonesia as an ecocracic country: The state's responsibility and the people's participation in preserving and in managing the environment quality. Qual Access Success. 2020;21(179):???.

15. Muhammad FS, Saleha S. Textbook on Health and Midwifery Organization and Service Management. Jakarta: Salemba Medika; 2019.

16. Sampurno B. Final Report of the Compendium Team of Legal Health Research and Development of the National Legal System, National Legal Development Agency, the Republic of Indonesia's Ministry of Law and Human Rights. Jakarta: Kemenhumham RI; 2021.

17. Muhammad R. Daily Movement Data for COVID-19 Positive Cases Until April 15, 2021, Berita Satu Official Account, Jakarta; 2021. Available from: https://www.beritasatu.com/beritagrafik/760989/data-pergerakan-kasus-positif-harian-covid19sampai-15-april-2021 [Last accessed on 2021 May 06].

18. Presidential Office Republic of Indonesia. President Joko Widodo Received First COVID 19 Vaccine. Jakarta: Presidential Office Republic of Indonesia; 2021. Available from: https://www. presidenri.go.id/siaran-pers/presiden-jokowi-menerima-vaksincovid-19-perdana [Last accessed on 2021 Apr 28]. https://doi. org/10.32493/sns.v1i2.10818

19. Ministry of Women and Child Protection Republic of Indonesia. Providing Guarantee of Safety and Comfort, Ministry of PPPA Implements COVID-19 Vaccination for Women and Children Victims of Violence, Jakarta; 2021. Available from: https://www.kemenpppa.go.id/index.php/page/read/29/3205/ berikan-jaminan-rasa-aman-dan-nyaman-kemen-pppalaksanakan-vaksinasi-covid-19-bagi-pendamping-perempuandan-anak-korban-kekerasan [Last accessed on 2021 Jun 04]. https://doi.org/10.31219/osf.io/xv24b
Author Queries???

AQ1: Kindly provide author initial

AQ2: Kindly check the reference

AQ3: Kindly provide Year

AQ4: Kindly provide last accessed details

AQ5: Kindly provide in page number 